\title{
RESENTMENT - EXCAVATING A RESURGENT PHENOMENON IN CONTEMPORARY SOCIETY
}

\author{
Anthony Balcomb \\ University of KwaZulu-Natal
}

Resentment is the greatest poison to the happiness of the human mind. ${ }^{1}$

I bear my grudge for reasons of personal salvation. ${ }^{2}$

Ressentiment brings about its most important achievement when it determines a whole "morality," perverting the rules of preference until what was "evil" appears to be "good." 3

\begin{abstract}
Resentment is a powerful human emotion that has both private and social dimensions where it manifests in a variety of ways. It has been identified as the force behind uprisings against racial, economic, and political inequality and injustice throughout time, as well as in the contemporary scene. Its moral and socio-political implications have been reflected on ever since Nietzsche identified it as a major contributing factor in the genealogy of morality. Max Scheler made a brilliant phenomenological analysis of it, and Francis Fukuyama recently identified it as a significant force in shaping contemporary identity politics. It has become a significant political force in contemporary South Africa, where the politics of reconciliation have largely been displaced by the politics of resentment. Although it has generally been viewed as having negative consequences for the social compact, its moral justification in specific circumstances has been powerfully made by the holocaust survivor Jean Amery and more recently by Didier Fassin with regard to post-apartheid South Africa. However, it is often accompanied by what Nietzsche called the "falsification of the tablets of value", which also means that it may lead to alternative mental constructions of reality that might result in delusional perspectives that can have dire social and moral consequences.
\end{abstract}

Keywords: Resentment; Inequality; Justice; Revenge; Morality; Dignity; Epistemology

Smith, A. 2013. On the politics and ethics of moral emotions in Didier Fassin, On resentment and ressentiment: Current Anthropology 54(3), 249-267, p 255.

2 Amery, J. 1980. At the minds limits, contemplations by a survivor on Auschwitz and its realities. Bloomington: Indiana University Press. Kindle Edition, p 80.

3 Scheler, M. 1972. Ressentiment, Translated by William Holdheim. New York: Schocken Books, p 28. 


\section{Introduction}

Since the killing of George Floyd by a white police officer on May 25, 2020, there has been a global uprising against racism of unprecedented proportions in the Black Lives Matter movement. The massive resentment, particularly from black people, that has been simmering for generations across the world has finally boiled over. The world is witnessing a manifestation of one of the most visceral, common, and fundamental of human emotions, as well as one of the most influential in terms of its impact on the human psyche and society. Everyone, if they have lived with any form of inequality, bears resentment at some time or another. History continues to demonstrate that resentment may start with a feeling, but given the right circumstances, ends with a revolution. In the contemporary scene, it has been linked to the politics of both left and right on the global stage and has been identified as the reason for Donald Trump's political success on the one hand and the wide-ranging rise of movements against oppression and injustice on the other (Fukuyama 2018). In this article I will offer a definition of resentment and then attempt to trace how the concept has been understood by several scholars, namely Nietzsche, who first mooted the idea that it was the original sentiment in the genealogy of morality, Francis Fukuyama, who traces its origins to the need for dignity, and Didier Fassin and Jean Amery, who attempt to rehabilitate it in the cause for justice and truth. Although I will not focus specifically on theological issues, they will constantly emerge during the course of the article and I will briefly summarise them at the end.

\section{What is resentment?}

Ressentiment is a state of repressed feeling and desire which becomes generative of values. The condition of resentment is complex, both in its internal structure and in its relations to various dimensions of human existence. While it infects the heart of the individual, it is rooted in our relatedness with others. On the one hand, ressentiment is a dark, personal secret, which most of us would never reveal to others even if we could acknowledge it ourselves. On the other hand, ressentiment has an undeniably public face. It can be creative of social practices, mores, and fashions; of scholarly attitudes, academic policies, educational initiatives; of political ideologies, institutions, and revolutions; of forms of religiosity and ascetic practices. (Morelli 1998:80-86).

This definition by Elizabeth Morelli is important in several respects. Firstly, it emphasises the sheer fecundity of the concept. This is not simply a feeling or emotion. It is a feeling that is "generative of values" and can have profound consequences for society in a multiplicity of ways. Secondly, it has both a psychological as well as a social dimension. The first is a private, dark, and hidden secret; the second is public, there for everyone to see and experience. The psychological aspect is so deep that we may not even ourselves be aware of its existence within us. Its social dimension, on the other hand, has an extraordinary array of manifestations that create attitudes, policies, initiatives, ideologies, institutions, revolutions, and religious beliefs. Thirdly, the relationship between its private and public dimensions is profoundly complex and makes the concept such an interesting one to unpack and pursue. Friedrich Nietzsche and Max Scheler are the most original thinkers on the topic. They used the French translation 
"ressentiment" instead of the English word "resentment" because, according to Scheler (1972:2), there was no equivalent word in the German. The French translation continues to be used by some scholars when they are specifically referring to the concept as it was originally conceived by Nietzsche.

\section{Resentment in Nietzsche and Scheler}

\section{Friedrich Nietzsche (1844-1900)}

Nietzsche's seminal treatment of the topic of resentment has served as a benchmark for its significance in shaping human interaction on a public level. In On the Genealogy of Morality, Nietzsche sets himself the task of trying to understand where the ideas of good and evil, right and wrong, come from. He rejects the idea that morality is based on an absolute set of divine laws which are somehow imprinted on the human soul and poses instead the theory that they emerge from the thwarting of the will to power, an idea that he gets from Arthur Schopenhauer. Out of the aggressive struggle to survive and flourish, there arose two classes of people - masters and slaves. ${ }^{4}$ The masters, rule, have power, and are able to do what they please. They live life, not just of immediate physical gratification, but of personal affirmation - the good life, out of which comes their understanding of the good, as opposed to the bad, which is the life being lived by the slaves, whom they treat with contempt. The slaves, because of their weakness, are relegated to the position of never being able to live the life that the masters are living. But they are relentlessly subjected to the frustration of having to witness their masters living this life while they remain in deprivation. It is out of such a situation that the slaves develop the feeling of what Nietzsche calls "ressentiment". According to Nietzsche, ressentiment drives the slaves to psychologically reconstruct their reality in such a way that helps them live with the idea that they can never be what the masters are, have what they have, and behave as they do. To help themselves overcome this, they falsify what Nietzsche calls the "tablets of value" to make them suit their predicament. They invent the notions of good and evil. Evil is what the master class is, loves, and does. Good is the opposite of this. So, for example, the notions of humility, love, and self-sacrifice are good, and pride, arrogance, and power are bad. The former belongs to the slave mentality and the latter to the master mentality. For Nietzsche, such falsification constitutes a slave revolt that has had profound political significance historically. It is the cornerstone of the Judaeo-Christian tradition. Jews, in the face of terrible persecution, have survived by creating for themselves a new reality and feed off their ressentiment and Christians, in a brilliant master stroke, have done the same. They have built around their founder Jesus Christ the entire edifice of their value system based on a carefully crafted defense mechanism that glorifies weakness and makes it a virtue. They invent the notions of humility, self-negation, and turning the other cheek. But this does not stop the feelings of envy, jealousy, rancour, hatred, and the desire for revenge. So, they invent the notion

\footnotetext{
The master/slave dialectic is originally from Hegel, not Nietzsche. His famous passage on the topic in "Phenomenology of Spirit" posits the emergence of self-consciousness through the life and death struggle between conscious entities that eventually manifests in the victory of one (the masters) over the other (the slaves). It is the slaves, however, who ultimately appear to have the last say as the masters continue to see themselves as the measure of all things while the slave achieves genuine self-consciousness. On this particular point, Nietzsche's thesis clearly differs.
} 
of sin, the need for forgiveness, and salvation. In short, they invent religion. This helps them to forget the present suffering and project themselves into a future bliss when they die. Priests, in Nietzsche's opinion, are the craven and cunning architects of this despicable lie. Although they belong to a particular category of the master class, they are marginalized within it and are therefore themselves infected with a particularly virulent strain of ressentiment and straddled between the master and slave realities, they ply their poisonous trade among the slaves in to ensure their continued servitude.

Nietzsche's theory of ressentiment can be summarised thus: Firstly, it is the unique experience of marginalised people who live in a situation of entrenched, existential (constantly experienced) inequality. Secondly, it is accompanied by feelings of impotence, a sense that there is nothing that one can do about this. Thirdly, it is accompanied by the invention of an alternate reality, which you construct to help you live with the situation and through which you develop a sense of justice and injustice, right and wrong, good and bad. The sum/total of this whole process constitutes the condition that Nietzsche and several subsequent thinkers called ressentiment.

\section{Max Scheler (1874-1928)}

Scheler agrees with Nietzsche's belief in the power of resentment, but is diametrically opposed to his theory that it constitutes the origins of Christian morality. As a Jew who converted to Christianity, he was a proponent of the idea that Christian morality was based on the unconditional love of God as manifested in Jesus Christ, and where the genuine love of God prevails, there is no possibility of resentment. However, he seems not to disagree with Nietzsche regarding its origins in the will to power. He writes extensively and in detail on what it is, what kind of people it affects and in what ways it affects them. His book is a brilliant exposé of the phenomenology of resentment. Ressentiment, he says, is the

... self-poisoning of the mind which has quite definite causes and consequences. It is a lasting mental attitude, caused by the systematic repression of certain emotions and affects which, as such, are normal components of human nature. Their repression leads to the constant tendency to indulge in certain kinds of value delusions and corresponding value judgments. The emotions and affects primarily concerned are revenge, hatred, malice, envy, the impulse to detract, and spite (Scheler 1972:4).

According to Scheler, there are two main sources of resentment - revenge and envy. Around each of these, a cluster of different feelings gather. For revenge, these include hatred, vengeance, rancour, and spite. For envy they include jealousy, the competitive urge, covetousness, ambition, vanity, shame, and greed.

\section{Resentment from revenge}

Resentment that comes from revenge starts with a sense of grievance, loss, or injury which begins with hurt of some kind. This leads to the desire for revenge. But you cannot take revenge because you are weaker than the person who inflicted you with the injury. So, you delay your response. Anger, frustration, and feelings of vengeance grow. You cannot forget what happened to you. You are constantly reminded of this by the presence 
of those who caused the injury in the first place. You delay your reaction, promising yourself to get your vengeance later. Your hostility grows into rancour, (defined by Mirriam Webster as "bitter deep-seated ill will") vengeance, the impulse to detract, and spite. These, according to Scheler, are only the precursors to resentment. They grow into full blown resentment when they are constantly repressed, recalled, and relived. Scheler is at pains to point out that this is not just a recollection of the events that led to the experience, but the actual reliving of the events and the experience. You repress them further because there is nothing that you can do to change the events, the circumstances leading to the events, and the experience of the events. By doing this, you remove them even further from the zone of action. The feelings of rancour and vengeance are increased with the sense of impotence, which causes further repression.

\section{Resentment from envy}

Resentment that comes from envy makes its appearance when you desire something another person has, but you cannot have. It may be an external object, or it may be an ability or strength that the other has and you do not. It is accompanied by a sense of impotence, because you do not have the power to obtain the object and shame, because this reflects on your own inability and weakness. The tension between desire and nonfulfillment leads to a hatred against the owner of the object who is then considered to be the cause of your privation. The more powerless you feel in obtaining the object, the more powerful the envy becomes.

The most powerless envy is also the most terrible. Therefore existential envy which is directed against the other person's very nature, is the strongest source of ressentiment. It is as if it whispers continually: "I can forgive everything, but not that you are - that you are what you are - that I am not what you are -indeed that I am not you." This form of envy strips the opponent of his very existence, for this existence as such is felt to be a "pressure," a "reproach," and an unbearable humiliation (Scheler 1972:10).

The object, gift, or ability is to be desired because it has a specific use in that particular society. But just as in the resentment/revenge scenario, where the object of revenge may disappear from the consciousness of the resentful, so also in the resentment/envy scenario. The usefulness of the object of envy can disappear long before the envy disappears. The object has become, in other words, not a means to an end but an end. Consumer societies, for example, continue to produce myriads of objects which must be obtained because they have become objects of desire without any obvious connection with their usefulness. You gain status and power simply by having them. Their purpose is merely to feed your vanity.

\section{Resentment as the basis of identity politics - Francis Fukuyama}

While for Nietzsche and Scheler the source of resentment is to be found in the thwarted will to power, Fukuyama traces its origins to a completely different source - the need for dignity. In the preface to his recent book, he talks about the unlikely stimulus that motivated him to write it - the fact that Donald Trump became president of the United States even though it seemed obvious that there could not have been anyone less suited 
for the job (Fukuyama 2018). The fact that he had been voted into office meant that millions of people in the United States, not only obviously liked him, but were also like him. This alarming reality set Fukuyama on the path of trying to find out why he was as he was and why he enjoyed so much support and argues that resentment is the force that propelled him into office.

Fukuyama first outlines the political background to the connection between resentment and identity and then excavates the psychology involved.

\section{Political background}

The globalisation that has taken place across the world from the 1970's to the early 2000 's led to the emergence of liberal democracies all over the world with political and economic policies that have on the one hand led to massive economic growth (the decrease in overall poverty has dropped from $44 \%$ to $17 \%$ during this period) and on the other massive inequality. This has led to a relatively small elite benefitting and huge disparities developing between the rich and the poor. The perceived difference between rich and poor countries, as well as intolerable socio-political conditions at home, led to tens of millions of people leaving their countries as refugees and seeking a better life elsewhere. The flood of refugees has taken place at the same time as the idea of liberal democracy has faltered and the world entered the Great Recession when the stock market collapsed in 2008, leading to massive unemployment in local economies which were at the time having to experience a fresh wave of immigrants. This led to the impression by locals that they were being deprived of their jobs, and this in turn led to the rise of rightwing nationalism in the countries concerned with rallying calls around racial, ethnic, and religious purity. On the left, blacks, women, refugees, Hispanics, and the LGBT communities have rallied around issues of race, gender, civil rights, and sexuality. The rise of radical Islam has been part of this trend. The decline of Islam from the glory days of its past has been accompanied by an increasing sense of alienation on the part of Muslims in secular western societies.

Marginalisation, inequality, and alienation have fuelled resentment at every level, between the rich and the poor, the powerful, and the powerless. As a result of this, huge groups of marginalised people have had to watch while the educated elite get richer and they seem to get poorer. The experience of inequality has been exacerbated by the widespread availability of the internet and social media. People are being made to directly experience the differences in wealth between themselves and the rich and educated elite through the immediacy brought about by the internet and cell phones, which have become ubiquitous among the poor as well as the rich. People can see, hear, and feel the differences. The fact that the overall wealth of nations has increased, is beside the point. It is the perceived difference in wealth and privilege that matters. Resentment takes place not just when inequalities exist, but when they are seen and experienced to be existing.

The most significant contribution that Fukuyama makes to this discussion, however, has not been his political analysis, as important as this is, but in his observation concerning what it is within the human being that makes him or her so prone to resentment in the first place. The answer for him is simple - it is the need for dignity. 


\section{Resentment, humiliation, and the need for dignity}

For Nietzsche and Scheler, it is the thwarting of the will to power that is the basis of resentment; for Fukuyama, it is the crushing of people's dignity. While discrepancies in material wealth cause resentment, Fukuyama argues that far more powerful feelings of resentment are engendered when a group's dignity has been crushed, disparaged, or otherwise disregarded. The burden of humiliation is greater even than the burden of poverty. He cites as examples Russian humiliation at the dissolution of the USSR and Putin's popularity because of his attempts to restore former Russian pride, the rise of Hungarian nationalism under Viktor Orban who wants to "restore the self-esteem of Hungary" and China under Xi Jingping who talks about restoring the "one hundred years of humiliation" suffered by attempts by the west to prevent it from becoming a global power as it used to be in the dynastic period. Finally, it is resentment that is behind the rise of radical Islam, which continually harks back to the days of the caliphates. Closer to home, we can point to the role that the humiliation of the Afrikaner under the British during and after the Boer War played in the creation of apartheid which, in turn, caused the humiliation of black South Africans and the rise of revolutionary movements such as the African National Congress. But what is it about dignity that makes it the source of resentment?

\section{Dignity, the third part of the soul}

Fukuyama traces the source of the notion of dignity back to the conversation between Socrates and his two debating partners, the aristocratic Athenian brothers in Plato's Republic. The discussion was around what constituted the essence of the human soul. They all agreed that reason and desire were two of these essentials - with desire being the thing that makes us reach out for fulfilment and satisfaction and reason the thing that helps us to calculate how this can be done. But there was a third thing that acted as a kind of arbitrator or umpire between desire and reason. When desire gets the better of us and reason is too weak to prevent its overreach, this third thing enables us to reflect on the consequences of our actions and bring us to our senses. Fukuyama uses the example of the drug addict whose desire to get a fix is not prevented by his reason, which tells him that this will lead him further down the path to destruction and who gets angry with himself when he succumbs. Socrates uses a new word for this third thing that causes anger and self-loathing, the word thymos. Thymos is neither desire nor reason, but acts completely independently of these. More than two millennia before the advent of modern economics, according to Fukuyama, Socrates had hit on the notion of the seat of judgement between desire and reason, the notion of worth. The recognition of our worth can come from within ourselves or, just as importantly, from others around us, but if it is not there then we are not fully human. This is the thing we call dignity, which is as fundamental to our make up as food, water, shelter, sex, and social cohesion. If we make positive judgements about ourselves, we feel pride; if we make negative judgments, we feel anger or shame. Fukuyama asserts that it is thymos that is at the heart of modern identity politics. While a great deal of emphasis, he says, has been placed on the need for material satisfaction and the closing of the poverty gap, not enough has been placed on the need for dignity. The assertions of black, LGTB, and women communities are not so much that they are materially disadvantaged as that their worth has not been recognized. The "MeToo" movement spread like wildfire and brought people like 
Harvey Weinstein to their knees because the dignity of his victims had been crushed. The Black Lives Matter movement has spread like wildfire throughout the world because millions of blacks will no longer tolerate a demeaning of their sense of self-worth.

Fukuyama traces the progress of the concept of dignity from its Greek origins through to modernity.

\section{The modern link between dignity and identity}

Fukuyama suggests that modern notions of identity have grown out of the tension that exists between the individual's own view of him- or herself and the view that the society has of him or herself. This tension between the outer self, which is the self that society demands us to be, and the inner self, which is our authentic self, is a uniquely modern phenomenon whose historical sources lie, according to Fukuyama, in the struggles of a certain sixteenth-century Augustinian monk by the name of Martin Luther. Fukuyama links Luther's struggle against the Catholic Church in his search for assurance of salvation with the modern self's struggle for authenticity over against the wider society's tendency to deny such personal authenticity. Resentment arises in the struggle of the "true inner self", associated with the notion of dignity and society's attempt to devalue and crush it. So, resentment arises with the tension between the self and society's expectation of the self and the belief that society must change, not the self. Luther paved the way for this radical state of affairs by acting on the conviction that he was right in believing that only God could save him and that the Catholic Church was wrong in believing that it was only the Catholic Church that could save him. He pioneered the path of self-acceptance when, unable to find acceptance by God through the agonising mortification of his flesh, he finally found both acceptance of himself and God when he accepted the fact of his sinful nature and trusted in God to forgive him. This realisation was accompanied by the realisation that he was being forced to live a lie that was being told him by the Catholic Church. Just like everything else Luther believed and did, he had little idea of the implications it would have not only on the church, but on the world. His insistence that it was only and entirely his faith in the finished work of Christ that could save him effectively repudiated the entire magisterium of the Catholic Church, which taught that it, the Church, was the vehicle of salvation. "In one stroke", says Fukuyama (2018:27), "he undercut the raison d'etre of the Catholic Church". He had started a fire that could not be put out, that swept through the entire society, reverberated through history, and paved the way for the modern notion of the will of the individual over against the will of the society. It brought about, in Fukuyama's (2018:27) words "the decline of Rome as the Universal Church, the rise of alternative churches, and a whole series of social changes in which the individual believer was prioritized over prevailing social structures."

\section{Resentment as a moral imperative - Didier Fassin and Jean Amery}

While Nietzsche and Scheler's phenomenological exposés of resentment largely emphasise its negative impact on both individual and society and Fukuyama's shows that it has its origins in damaged dignity and can lead to profound social change, Didier Fassin attempts to demonstrate that it plays a necessary role in bringing to light the ethical and moral dimension in human interactions. He begins with how resentment has been understood negatively by thinkers such as Adam Smith who argued in his Theory 
of Moral Sentiments that it was an "unsocial passion", compared to the "social passion" of sympathy. Smith believed that while resentment is a necessary part of human nature as it demonstrates the contemptibility of the person "who tamely sits still, and submits to insults, without attempting either to repel or to revenge himself", it is still a "disagreeable emotion" that is "the greatest poison to the happiness of the human mind" (Smith in Fassin:2013:251). He concedes, however, that resentment can have positive social implications if it is not accompanied by feelings of revenge and leads to a change of conduct in the person who caused the resentment in the first place. So, resentment can be legitimate if it is accompanied by a sense of mercy and social duty.

Fassin describes a more positive assessment of resentment in the theology of Joseph Butler whose 1827 sermons on the topic wrestle with the question of why it is that God placed an emotion in the human heart that seemed to be so opposite to that of benevolence, which is the "great law of the whole moral creation" (Butler in Fassin:2013:251). Butler distinguished between "hasty and sudden" resentment and "settled and deliberate" resentment that "represents to our mind injustice or injury". The former he describes as "natural" and the latter as "moral". He describes resentment as "the indignation one feels when confronted with injustice inflicted on others or to oneself and the desire to have it punished" and concludes that it is a passion that has been implanted by God in people "to prevent and remedy such injury, and the miseries that arise from it" (Butler in Fassin 2013:251).

However, it is in the work of Jean Amery where Fassin finds a more complete rehabilitation of resentment. Amery establishes a foundation for the idea that the resentment of victims of institutionalised violence and injustice is a moral necessity in societies where heinous political crimes are too easily forgotten for the sake of social cohesion and economic development. As one of the case studies to demonstrate his argument, he uses post-apartheid South Africa in the light of the Truth and Reconciliation Commission. Jean Amery was a Jew who was tortured by the Nazis in the infamous concentration camps of Auschwitz and Belsen-Bergen. In his attempt to restart his life after torture, he went to the extent of changing his name from Mayer to Amery. He eventually took his own life, unable to live in a world which behaved as though nothing had ever happened under the Nazi regime and in the concentration camps. It turned out that the psychological torture of living in a society composed of people who for twelve years had "joyously celebrated a festival of cruelty" and who now behaved as though nothing had happened and expected him to forgive and forget was as great as the physical torture he had experienced at the hands of the Nazis.

It is very difficult to portray Amery's argument adequately in justifying his resentment since it is so profoundly connected with his intensely personal experience of suffering. His feelings are best communicated with the words he himself uses and one is therefore constantly forced to quote him verbatim. I will attempt very briefly to summarise the task that he sets himself and then use his own words to summarise the conclusion that he comes to.

\section{Amery and the justification of resentment}

Amery attempts firstly, to accept that his resentment, in view of the post-war society of Germany, is a "sickness"; secondly, to realize that it is "an integrating part of [his] personality"; and thirdly, to legitimise it. This entails justifying a psychic condition that 
moralists condemned as a taint and psychologists viewed as a sickness (Amery 1980:64). Amery is fully cognizant of the impossibility of the task that he sets himself, recognising that resentment is both an "unnatural" and "logically inconsistent" condition because it "nails every one of us onto the cross of his ruined past" and "demands that the irreversible be turned around, that the event be undone". But to deny his resentment was to "accept a parallelism that would have my path run beside that of the fellows who flogged me with a horsewhip" (Amery 1980:69) and thus become an accomplice with his torturers. The problem for Amery was that the crimes committed under National Socialism were not seen as such by the perpetrators. They were simply "facts within a physical system, not deeds within a moral system". Where there is no morality there is no "chain of conscience" that locked the monster to a moral deed and therefore no need for repentance and forgiveness. The deeds were simply seen as the objectification of the will of the Führer and his Reich.

Amery's intense and often harrowing self-analysis leads to the following justification of his resentment.

In two decades of contemplating what happened to me, I believe to have recognized that a forgiving and forgetting induced by social pressure is immoral. Whoever lazily and cheaply forgives, subjugates himself to the social and biological timesense, which is also called the "natural" one. Natural consciousness of time actually is rooted in the physiological process of wound-healing and became part of the social conception of reality. But precisely for this reason it is not only extramoral, but also antimoral in character. Man has the right and the privilege to declare himself to be in disagreement with every natural occurrence, including the biological healing that time brings about. What happened, happened. This sentence is just as true as it is hostile to morals and intellect. The moral power to resist contains the protest, the revolt against reality, which is rational only as long as it is moral. The moral person demands annulment of time - in the particular case under question, by nailing the criminal to his deed. Thereby, and through a moral turningback of the clock, the latter can join his victim as a fellow human being (Amery 1980:68).

With Amery's legitimisation of his resentments in mind, Fassin shifts his attention to the post-apartheid situation in South Africa and the work of the Truth and Reconciliation Commission. His clarification of the need to use the term ressentiment as opposed to resentment is well summarised in the following quote:

The choice of the word "ressentiment" rather than "resentment", indicates affirming an anthropological, rather than psychological, signification to his [Amery's] position, but legitimizing it from a moral instead of emotional, perspective. The man who invokes ressentiment as a personal stance toward his former torturers is neither the man of ressentiment, whom Nietzsche associates with revenge, nor merely a resentful man, whom Smith would be willing to absolve; he is a man defending a form of dignity that is increasingly censored and that has become unintelligible (Fassin 2013:253, emphasis mine). 
Fassin thus, reinforces the idea mooted by Fukuyama that crushed dignity is the original source of resentment and applies it to the post-apartheid South African scene with respect to Thabo Mbeki's denialism. He picks up on the "as if nothing had ever happened" theme with which Amery struggled to come to terms in the aftermath of the Nazi Germany experience and applies it to the situation in South Africa in the aftermath of apartheid. Just as Amery had been pressured to forgive and forget for the sake of moving the country forward, so the victims of apartheid, through the Truth and Reconciliation Commission, were encouraged to do in South Africa. But this was based on the belief that resentment, which is based on non-forgiveness, was antisocial and bad for the country. Such a sentiment however, according to Fassin, does not take into consideration the enormity of the injustices of apartheid and the depth of the psychological damage that the racist policies of apartheid had inflicted on black South Africans. And just as resentment could be morally justified in post-Nazi Germany, it can be morally justified in post-apartheid South Africa. Fassin identifies Mbeki as the quintessential "man of ressentiment" and Mandela the quintessential man of reconciliation. Fassin does not further interrogate the moral appropriateness of the Mandela/Tutu legacy of reconciliation, but the negative implication is clearly there.

\section{Is resentment justifiable? A critical evaluation of the discussion so far}

The two sources of resentment identified in this article point to two different understandings of resentment, both of which are convincingly argued by their protagonists. On the one hand is the Nietzschean perspective which is associated with the thwarting of the will to power, which results in a veritable Pandora's box of the most unvirtuous attitudes, feelings, and intentions. On the other hand, is a perspective that argues that resentment is a necessary and legitimate reaction against gross and humiliating injustice. The word "poisonous" is constantly used to describe the former and the word "moral" to describe the latter. But the discussion itself indicates that such a binary approach is not justified, and the phenomenon demands a far more nuanced understanding. Can the resentment of Amery really be compared with the resentment of Trump? Was the resentment of Luther not entirely justifiable, and did this not have immensely positive consequences for humankind? Indeed, where would we be if Luther decided to forgive the Catholic church rather than nail his thirty-nine theses to the chapel door? Did not Amery also experience the feelings that Scheler describes of the resentful person as he embarked on the project of engendering unrequited resentment, and if he did, does this make his resentment morally invalid? Does the picture of a white policeman crushing the life out of a helpless black man pinned to the ground and begging for mercy not justifiably enrage every justice-loving human being in the world and set them on the righteous path of implacable resentment toward abuse of white power?

These questions, rhetorical as they are, intend to reinforce the moral justifiability of resentment. However, they should not blind us to its potentially disastrous consequences. Resentment can just as easily result in the mendacity of a Trump as it can in the righteous indignation of an Amery. Scheler's insights on "organic mendacity" are extraordinarily appropriate to Trump in this regard.

What is called "falsification of the value tablets," "reinterpretation," or "transvaluation" should not be mistaken for conscious lying. Indeed, it goes beyond 
the sphere of judging. It is not that the positive value is felt as such and that it is merely declared to be "bad." Beyond all conscious lying and falsifying, there is a deeper "organic mendacity." Here the falsification is not formed in consciousness, but at the same stage of the mental process as the impressions and value feelings themselves: on the road of experience into consciousness. There is "organic mendacity" whenever a man's mind admits only those impressions which serve his "interest" or his instinctive attitude. Already in the process of mental reproduction and recollection, the contents of his experience are modified in this direction. He who is "mendacious" has no need to lie! In his case, the automatic process of forming recollections, impressions, and feelings is involuntarily slanted, so that conscious falsification becomes unnecessary. Indeed the most honest and upright convictions may prevail in the periphery of consciousness (Scheler 1972)

There are numerous examples of such "transvaluation", "reinterpretation", or "falsification of the value tablets" when resentment is at play, no matter how justifiable it might be. Besides Trump, two well-known examples are worth mentioning - Thabo Mbeki and O.J. Simpson.

In 2006, I published an article interrogating Mbeki's denialism and argued that it was indeed his resentment, not only of apartheid, but the entire legacy of colonialism and the image that it promoted of the black man that was behind it. This was made especially obvious in his frequent tirades against those who disagreed with him on the Aids issue, as I argued.
'Yes, we are sex crazy! Yes, we are diseased! Yes, we spread the deadly HI virus through our uncontrolled heterosexual sex! In this regard, yes, we are different from the US and Western Europe! Yes, we, the men, [my emphasis] abuse women and the girl-child with gay abandon! Yes, among us rape is endemic because of our culture! Yes, we do believe that sleeping with young virgins will cure us of AIDS! Yes, as a result of all this, we are threatened with destruction by the HIV/AIDS pandemic! Yes, what we need, and cannot afford because we are poor, are condoms and anti-retroviral drugs! Help! $!^{5}$

The sarcastic "yes" which peppers this extraordinary statement should not obscure the anguish that is behind these words. The anguish of the intolerable image that he has of the image that the West has of Africa and Africans (Balcomb 2006:107-108).

Fassin's sympathetic entertainment of Mbeki's resentment is understandable in the context of his argument about the moral intolerability of living as though apartheid had never happened. Mbeki's anguish, indeed, the anguish of all the victims of the racist legacies that lie behind colonialism and apartheid, cannot be underestimated, least of all by those who have never been on the receiving end of their dehumanising effects. However, the kind of thinking that his resentment led to is surely a classic example of what I have called the reinvention of truth and what Nietzsche and Scheler called the "falsification of the tablets of value". By allowing himself to be influenced by his resentment, he devised and implemented policies that were universally condemned and 
that led to the deaths of thousands of people with Aids. It is somewhat puzzling, therefore, that Fassin does not recognise this in his apology for Mbeki's resentment.

The second classic example, is that of O.J. Simpson. Although all the evidence pointed to the fact that he was guilty of the murder of his wife, a predominantly black jury pronounced him innocent. One of the jurors was a former member of the Black Panthers and he rose to his feet to give the black power salute at the announcement that he was not guilty. A year later, in a civil trial that was not broadcast live, the jury unanimously found him guilty of the same offence. He was fined 33million dollars, which he never paid back. Instead, he continued to live the high life. But very few people believed that he was innocent, even before the civil trial. Lionel Cryer, the juror who gave the black power salute when Simpson was declared not guilty, admitted in retrospect that he should have given a guilty verdict. Carrie Bess, another black member of the jury, said that she believed that $90 \%$ of the jury gave a non-guilty verdict in revenge for the Rodney King incident. Rodney King was a black construction worker who was pulled from his car and severely beaten up by a police officer in Los Angeles allegedly for resisting arrest in 1992. The entire incident was caught on camera. The police were arrested for brutality, and an all-white jury found them not guilty. The resentment that these actions engendered, as justifiable as it was, ultimately led to the false declaration of Simpson's innocence with profoundly negative consequences in the long run for the righteous cause of the rights of the African American people in the United States of America.

The mendacity of Trump, denialism of Mbeki, and revenge of the OJ Simpson jury all point to the serious consequences that potentially accompany resentment. This begs the question whether resentment such as that borne by Jean Amery could have similar consequences. While the social consequences of Amery's resentment are difficult to discern the bare fact that he took his own life because of them surely points to the direness of their consequences.

\section{Conclusion: resentment as a theological and moral challenge}

In this article, I have attempted to describe how the concept of resentment has evolved over time in the minds of thinkers. However, we understand it, it is a phenomenon that we can no longer ignore: has its influence become so obvious in contemporary world affairs in general, and in South Africa in particular, where, as one of the most unequal societies in the world, the zeitgeist has shifted from reconciliation to resentment after the demise of Mandela. Indeed, it is precisely Mandela's extraordinary lack of resentment and his legacy of reconciliation that is now coming under attack in the wake of the failure of the ANC to deliver on the promises of equality for all. All the ingredients that Nietzsche identified as giving rise to resentment (existential inequalities based mainly, in this case, on race), feelings of impotence (presenting as frustration and manifest in violent demonstration) and ensuing construction of an alternative set of values which are used to justify criminality (quintessentially expressed in Jacob Zuma's inability to believe that he has done anything wrong) are all too manifest in the contemporary scene.

In this article, I have included a diversity of perspectives on the topic because each of the thinkers I have used contribute to our understanding of it. While in some respects Nietzsche got it profoundly wrong, in others his reflections are right. He was wrong if he thinks that the ethic of Jesus reflects weakness. On the contrary, this ethic comes out 
of profound strength. Everyone knows that it is far easier to strike back at one's aggressor than it is to "turn the other cheek", especially when such a reaction is accompanied by dignity, the original need that, if crushed, gives rise to resentment as identified by Amery, Fukuyama, and Fassin. Such dignified strength is extremely rare, but where it has been demonstrated, it has proved profoundly effective - as the lives of Jesus of Nazareth, Martin Luther King Junior, Mahatma Ghandi, and Nelson Mandela so starkly demonstrate. But Nietzsche's other insights are profoundly significant, most notably his insight that resentment emerges out of structural inequality, that it is accompanied by a sense of impotence, and that it has epistemological implications, that is it affects deeply not only our sense of what is right and wrong, but how we interpret and understand the realities that surround us. Given the right circumstances, for example, if you are a Mbeki, a Zuma, or a Trump, this can have far reaching and profound negative implications. Scheler's interpretation of Nietzsche is deeply significant when we consider it in the light of Fukuyama's assertion that most of Donald Trump's rants come out of his resentments. His observation that "falsification of the tablets of value" is indicative of "organic mendacity" rather than blatant lying is extraordinarily applicable to Donald Trump. Yet, despite of such deadly consequences to having it, who can deny the right of resentment to people such as Jean Amery, the victims in the Me Too and Black Lives Matter movements and, indeed, Thabo Mbeki? Who can deny it to every person who has ever lived and experienced the trashing of his or her dignity? Resentments run deep and they run long. And those who have them will hold them as though their lives depended on it. To the resentful, they are important beyond telling because the dignity of those who hold them is important beyond telling. "I bear my grudge", says Amery (1980:80), "for reasons of personal salvation". This is an astonishing admission. Resentment, in other words, was all he had left in life, his pearl of great price, the thing for which one sells all one must buy the ground in which it is buried, the most treasured possession, without which there is no meaning. This surely gives new meaning to the idea of "nursing" one's resentments. He who wants to lose his salvation will relinquish his resentment. Yet, if the gospel is true, the opposite is true. To gain one's salvation is to lose one's resentment. But for Jean Amery, this, tragically, seemed too easy a way out of the agonising dilemma that faced him and with which he could not live.

\section{Epilogue - theological themes and the burden of forgiveness}

While this article has not focussed specifically on theological issues that emerge around resentment, the topic is freighted with theological significance. I have only very briefly responded to Nietzsche's theory of religion being based on resentment and Scheler's rejection of this thesis based on the doctrine of the unconditional grace of God which is in turn reinforced by Fukuyama's thesis that Luther was the first to assert the realisation of the worth of the individual over against society. This theme offers a veritable treasure trove of theological possibilities as it is directly linked with the notion of dignity which in turn resonates with the doctrine of the imago dei. Fassin and Amery introduce the question of forgiveness and reconciliation by way of offering an apology for resentment. Much more, of course, could be said about this. If resentment has both a personal as well as systemic dimension, embedded as it is in both the individual, as well as the structures of society, so, arguably, should forgiveness. If resentment is an attitude that, given the right circumstances, culminates in a revolution, is it not possible that forgiveness could 
also be an attitude that culminates in a revolution? The circumstances around such a possibility may be far more difficult to unpack, given the fact that it is hard to understand how forgiveness could be as contagious as resentment, at least without divine intervention. Scheler's remarkable ability to place himself in the shoes of the "man of ressentiment" has a chilling ring of truth in the following words - "I can forgive everything, but not that you are - that you are what you are - that I am not what you are, indeed that I am not you". This statement is especially significant when seen in the light of the history of the first conquests of Africa and the Americas, the latter going back five hundred years and the former two hundred. The question on the minds of the conquistadors, asked with all seriousness, was whether the indigenous peoples were human beings, since it was not apparent that they had any religion, which, for them, was the hallmark of humanity. And since they did not apparently have a religion, genocide was a theologically justifiable option in the eyes of the conquistadors. The attitude of the early colonisers of Africa were not wholly dissimilar, especially towards the original peoples of Africa, the San. A theology of forgiveness will have to consider destroyed dignities that go back a very long way in time. They, the colonisers, "are what they are", implying that they will never change, that they will for ever be the masters, and the colonised "are not what they are, are not them", and will forever be the slaves. The implication is dark, as each will always and forever be the "other", unable to be equal, unable to change, and unable to be forgiven.

\section{BIBLIOGRAPHY}

Amery, Jean. 1980. At the minds limits, contemplations by a survivor on Auschwitz and its realities. Bloomington, Indiana University Press, Kindle Edition.

Balcomb, Anthony. 2006. Sex, sorcery, and stigma - Probing some no go areas of the denial syndrome, Journal of Theology in Southern Africa , 104-114.

Fassin, Didier. 2013. On resentment and ressentiment, Current Anthropology, 54(3).

Fukuyama, Francis. 2018. Identity - the demand for dignity and the politics of resentment. London, Profile Books, Kindle edition.

Nietzsche, Friedrich. 2006. In Ansell-Pearson, Keith (ed.), On the genealogy of morality. Cambridge University Press, Cambridge translated by Carol Diethe.

Scheler, Max. 1972. Ressentiment. New York, Schocken Books, Translated by William Holdheim. 